\title{
The World Experience in the Regulation of the Land Circulation
}

\author{
By Grygorii Kaletnik ${ }^{1}$, Inna Honcharuk ${ }^{2}$, Tetiana Yemchyk ${ }^{3}$, Yuliia Okhota ${ }^{4}$
}

\begin{abstract}
The article examines the state of the agricultural development in Ukraine in the context of the crop and livestock industries. The use of land resources by different owners and the structure of agricultural land were also analyzed. The problems of the development of the electronic cadastre of the land resources were identified. The proposals to use the world experience of agricultural land use in Ukraine were substantiated. The proposals for the improvement the legal framework in the field of the agricultural land circulation were elaborated.
\end{abstract}

Keywords: land market, gross production, world experience, crop production, animal busbandry, land resources

\section{Introduction}

The land is the main national wealth and basic object of the economic system of Ukraine. There is no doubt that food security of the state, rational and environmentally friendly use of its most valuable wealth - land resources, increase of the efficiency of agricultural production and investment climate, further development of market transformations in the agrarian sector depends on the successful functioning of the land market.

The land is one of the most important strategic economic resources whose management must have the strategic character in the application of the most effective management principles and mechanisms, especially for countries for which land forms a significant share of the state's income. Therefore, Ukraine stands before the important task of the development of its own model of the land relations, having unique natural potential and taking into account the experience of other countries.

Based on the definition of the moratorium on the sale of the agricultural land, it is obvious that its existence is a temporary phenomenon, and it is necessary to form a new concept of the land market relations. At the same time the main task is to choose such a model of the land market that takes into account centuries-old traditions of management, the best international experience of the functioning of the land relations, the main tendencies of the development of the agricultural sector and at the same time ensures the compliance the principles of the sustainable development of the Ukrainian economy.

\footnotetext{
1 Doctor of Economic Sciences, Professor, Academician of NAAS of Ukraine, President of the Ukrainian Research and Educational Consortium, Vinnytsia National Agrarian University, Vinnytsia, Ukraine.

${ }^{2} \mathrm{PhD}$ in Economics, Associate Professor, Department of Economics, Vice-Rector for Scientific and Innovative Activities, Vinnytsia National Agrarian University, Vinnytsia, Ukraine.

${ }^{3} \mathrm{PhD}$ in Economics, Associate Professor, Department of Agrarian Management, Vinnytsia National Agrarian University, Vinnytsia, Ukraine.

${ }^{4}$ Postgraduate Student, Department of Administrative Management and Alternative Energy Sources, Vinnytsia National Agrarian University, Vinnytsia, Ukraine.
} 


\section{Literature Review}

Last time the theoretical questions of land valuation of the agricultural land were devoted the work of such scientists as Kaletnik, G., Shubravska, O., Ibatullin, M., Krysanov, D., Starychenko, Y., Tkachenko, K., Varchenko, O. (2019), Popek, S., Sikora, T. (2005), Butnaru, S.E. (2015), Lupenko, Y., Khodakivska, O. (2016), Khodakivska, O. (2015), Kyrylenko, I. (2017)., Yaremko, V., Niev'evskiy, O., Zarytska, M. (2017), Zalutsky, I. (2017), Zhaohui Hong, Yi Sun (2020), Berta, F., North, M., Rovere, S., Tatara, E., Macal, C., Podestá, G. (2015), Gladiy, M. (2020) and others.

However, the problems related to the organization and functioning of the land market in Ukraine are still unresolved, which makes the research relevant. Gradually they moved from the economic plane to the political one, exacerbating the social tension in the society, generating the political speculation around the land questions and provoking the creation of the shadow schemes for land alienation, land raiding and so on.

The uncertainty about the agricultural land market justly caused widespread mass perturbations among farmers and small land users. In view of these and other circumstances and taking into account the significant differences in the views of politicians, scientists, landowners and land users on the future model of the agricultural land market in Ukraine, the objective need to develop and broad discussion of the conceptual principles of the formation and implementation of agricultural land market recognition and introduction mechanisms of its regulation arose $[1,2,3,4]$.

However, the further exploration of the experience of the agricultural land market circulation and its use in the realities of Ukraine is the main purpose of this article.

\section{Materials and Methodology}

The peculiarities of regulation of agricultural land use in the world and Ukraine and the prospects of the application of the world experience in this field in domestic practice became the object of the study. In the process of research such methods as analysis and synthesis (in the process of research of components of development of agriculture of Ukraine taking into account the structure of property of land resources), monographic method (analysis of scientific achievements of Ukrainian and foreign scientists on problems of introduction of world experience of land use of agricultural lands) were used, abstract-logical analysis (theoretical generalizations and formulations of conclusions and proposals for the study) was also used.

\section{Results}

The task of the land reform in Ukraine was to eliminate the state monopoly of the land property and to restore the effective owner in the countryside. The intermediate stage of the land reform in Ukraine was the transfer the state property of the land to the collective property of the agrarian enterprises, which carried out its splitting or distribution into the land plots (shares) later. The members of these enterprises were given the single-sample certificates, which guaranteed the right for the land plot in the land array that was in the collective application. 
By decree of the President of Ukraine №666 / 94 of 10 November 1994 "On Immediate Measures to Accelerate Land Reform in the Field of Agricultural Production" [14] the transfer of land to the collective and private property for the agricultural production was provided. However, in our opinion, it is necessary to observe the norms that the land should belong to the persons which cultivate it. It underlines the expediency of the concentrating of the land resources on those owners which have both the desire and the ability to cultivate it effectively.

According to the results of the land reform that began in Ukraine since the first years of independence, 27.5 million hectares of land were divided through section and privatization. As a result of the shareholding, 6.9 million citizens of Ukraine acquired the right to the land part (share), and 6.8 million became their owners. Besides, the citizens received the land plots for the property and application for the agricultural commodity production, personal farming, gardening, hay mowing and grazing [4].

The actual availability of the right for the land property of 6.8 million citizens of Ukraine, which was caused by the land section of the collective enterprises, does not indicate the possibility of the rational and effective application of this resource. During the moratorium the state tried to form the civilized land market. However, the Law of Ukraine "On Land Lease" [15] did not form any safeguards for the creation of the huge agro holdings, among which 15 leased 3.32 million hectares collectively [6].

Thus, the preconditions for the introducing of the market land circulation and formation of the secondary market for the agricultural land were formed in Ukraine. In particular, at the beginning of 2019,31 million hectares of agricultural land or $74.95 \%$ of their area were in the private property. The part of the state property inludes $24.06 \%$, municipal $0.1 \%$, collective $-0.04 \%$ (Figure 1).

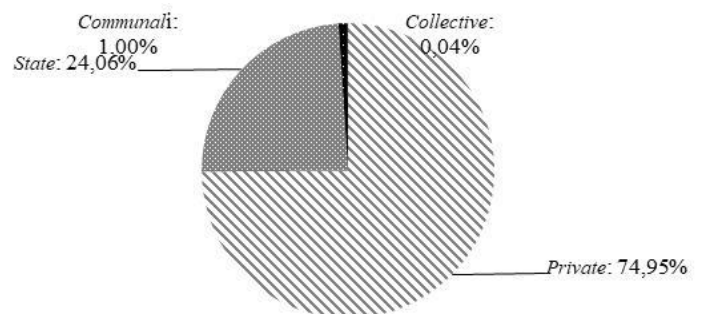

Figure 1. Structure of agricultural lands of Ukraine according the type of the property as of 01.01.2019

Source: developed by authors using data from State Statistics Service of Ukraine [5].

45,000 market-type agricultural formations were formed, among which $71 \%$ are farms, $17 \%$ are business associations, $8 \%$ are private enterprises, $1 \%$ are industrial cooperatives, and $3 \%$ are enterprises of other forms of management [5].

As a result of the first steps of the land reform in Ukraine the reform of the property relations in the agricultural sector had happened. In order to form the effective agricultural landowner and land user the state has granted a monopoly right to the agricultural land.

Examining the question of whether the efficiency of the agricultural commodity production as a result of the implemented state measures was succeeded, we see that in the initial period there was a significant decline in the gross production of the agricultural products (1999). After that the lift began, but we still can not reach the level of 1990 (Figure 2) [5]. 


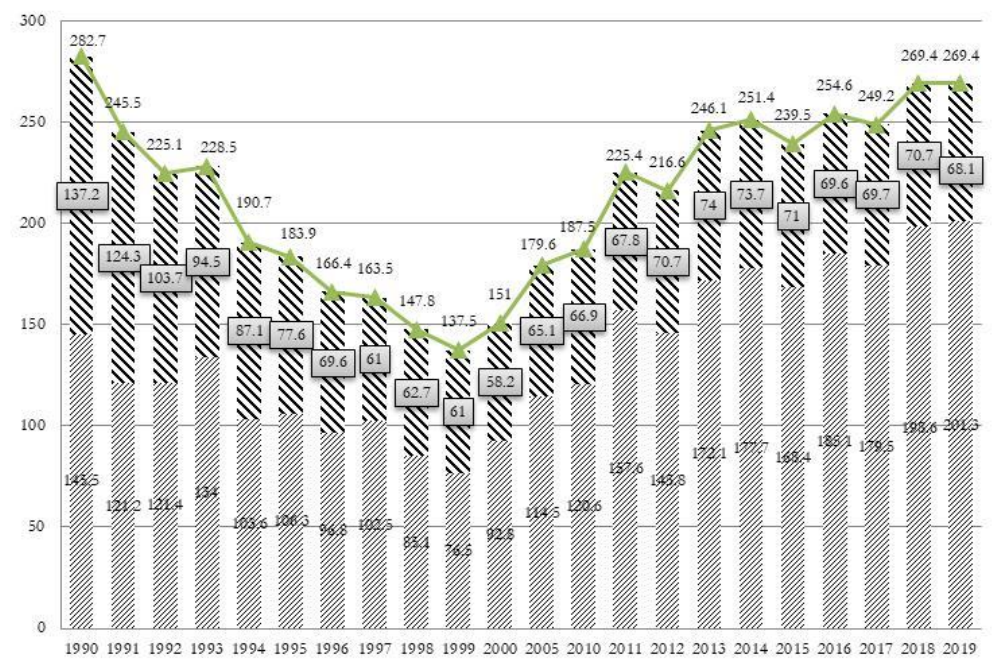

"IIIIII, production of plant grotring

'II' production of animal husbandry

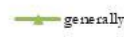

Figure 2. Agricultural output at constant prices of 2010 (UAH billion) as of 01.01.2019

Source: developed by authors using data from State Statistics Service of Ukraine [5].

If in 1990 the number of heads of cattle was 24623.4 thousand heads (including 8378.2 thousand heads of cows), in 2018 the cattle population was only 3510.8 thousand heads (including 1999.6 thousand of cows). Thus, the cattle population decreased by almost 7 times, cows - by more than 4. Besides, the number of pigs decreased (from 19426.9 thousand head in 1990 to 5970.8 thousand head in 2018), sheep and goats (from 8418.7 thousand head in 1990 to 1304.5 thousand head in 2018). Only the volume of poultry growing as a cheap substitute for pork and beef increases (Figure 3) [5].

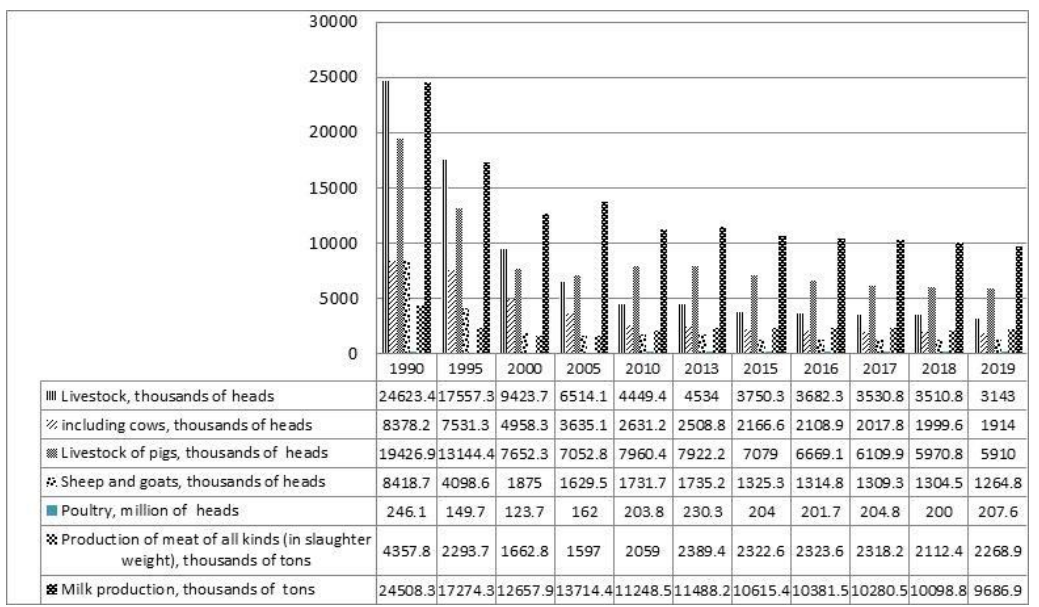

Figure 3. Dynamics of the number of livestock and production of basic types of animal husbandry as of 01.01 .2020

Source: developed by authors using data from State Statistics Service of Ukraine [5]. 
Therefore, when deciding on further reform of the land relations in agriculture, we should take into account both our own experience and the experience of foreign countries and, above all, experience of our neighbors.

In order to evaluate the consequences that we can get at present as a result of the introduction of the agricultural land market, we should try to answer some of questions. First. Who wants to sell land in Ukraine today? Owner of a land plot, owner of the personal peasant farm. The studies show that retirees are the landowners and they unable to work on land and who have acquired property rights but who do not live in the countryside and are unable to process or even receive their rent (as they live in other regions or outside Ukraine) have a desire to sell their allotment.

Of the 6.9 million shareholders almost 23\% (1.6 million shareholders) are over 70 years old. Thus, in the third quarter of 2015, in Ukraine 193184 land plots were inherited, 395 256 were transferred in 2016, and 190682 were transferred in 2017.

During the years of the reform 1.4 million shareholders died, among them 0.5 million did not manage to use their property: they did not leave left no heirs or heirs did not exercise their rights through the expensive inheritance process [6].

According to the State Geocadastre, in 20176723 land plots of the extinct heritage with a total area of 25448 hectares were recorded in Ukraine. For the period 2015-2017 the number of the land plots of the extinct heritage increased by 748 (or 13\%), and the area - by 2939 hectares (or 13\%) [6].

In case of the ban on alienation of the agricultural land allocated in kind (on the ground) as land plots (shares) the rent became the main instrument for the formation of the agricultural land use. According to the leading domestic scientists, the land relations in agriculture should be developed mainly on a lease basis, as one of the components of the land market, with the gradual formation of a full-fledged market circulation of the land.

It is necessary to note that leasing is a common form of the land use in the European Union. EU countries are quite different in the terms of rent among themselves. In particular, the agricultural enterprises of Slovakia and the Czech Republic carry out the economic activities mainly on the leased lands, the part of which is more than $90 \%$ in the total amount of land use.

The farms in France, Belgium, Germany and Estonia have more than $60 \%$ of the leased land, the UK - more than $40 \%$. The lowest part of the leased land is in Ireland, Denmark, Finland and Austria - up to 30\% (Table 1). In most EU countries the part of the leased agricultural land in the total area of agricultural land tends to increase [7].

Table 1. Part of own and leased land by EU farmers (as a percentage to the total area of the agricultural land)

\begin{tabular}{|l|c|c|l|c|c|}
\hline Country & Own lands, $\%$ & Rental lands, $\%$ & Country & Own lands, \% & Rental lands, \% \\
\hline Denmark & 76 & 24 & Sweden & 56 & 44 \\
\hline Poland & 72 & 28 & Estonia & 38 & 62 \\
\hline Austria & 71 & 29 & Germany & 32 & 68 \\
\hline Spain & 67 & 33 & Belgium & 25 & 75 \\
\hline Italy & 63 & 37 & France & 16 & 84 \\
\hline Netherlands & 62 & 38 & Czech Republic & 9 & 91 \\
\hline United Kingdom & 59 & 41 & Slovakia & 4 & 96 \\
\hline
\end{tabular}

Source: developed by authors using data of Khodakivska, O. (2015) [7]. 
At present the agricultural enterprises of Ukraine conduct business mainly on the leased lands, the part of which in total land use exceeds $95 \%$. In previous years the owners of the land units concluded the lease agreements mainly with the agricultural enterprises operating in the territory of the owners of the plots. However, this trend has some changes at present. In 2016 about $52 \%$ of the lease agreements in Ukraine were concluded with other business entities registered outside the territorial communities. In the vast majority of the lease agreements were concluded for 8-10 years, so the medium-term leases predominate (about 45\%). The part of the long-term leases increases - over 10 years (17\% versus $1.8 \%$ in 2000). There are almost no lease agreements concluded for $1-3$ years $(3 \%)$ [4].

The second question about the development of the land market - who is a potential buyer of land in Ukraine and in what quantity? First of all, they are the owners of large holdings with foreign capital. The purchase of land by farmers, small agricultural enterprises is unlikely at present, as it will lead to the withdrawal of the working capital from production and will lead to its curtailment. Even the sufficiently large agricultural producers declare their financial inability to purchase agricultural land at a rate that ensures profitable production at present.

In 2019 the average regulatory monetary value of arable land and fallow lands in Ukraine was $27,500 \mathrm{UAH} /$ hectare, taking into account the devaluation today, the average regulatory monetary value of land is $30000 \mathrm{UAH}$. The largest NGO is in Cherkasy (33 646 UAH / hectare), Chernivtsi (33264 UAH / hectare) and Kharkiv (32337 UAH / hectare), and the lowest - in Rivne (21938 UAH / hectares), Volyn (21 806 UAH / ha) and Zhytomyr (21 $411 \mathrm{UAH} /$ hectare) (Figure 4) [6].

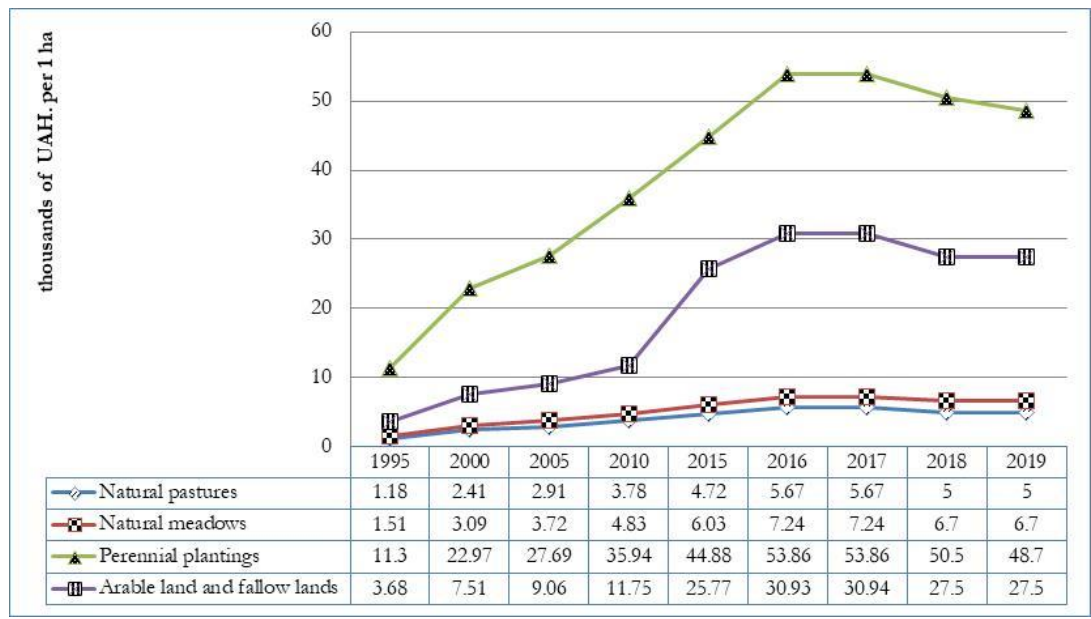

Figure 4. Dynamics of regulatory monetary valuation of the agricultural land as of 01/01/2020

Source: formed by the author according to the State Geocadastre [9].

Taking account that the average size of the plot is 4 hectares, the price of the plot in the market, in case of the lifting the moratorium, may amount 125 thousand UAH [8]. This is extremely small, because it is just over $\$ 4,5$ thousand. US per plot, or $\$ 1,150$ per 1 hectare in dollar equivalent at the average rate of the NBU [6]. 
Even at such price for the land small farmers and farmers will not be able to buy the land in case of the free sale of the land [9].

The proponents of the abolition of the moratorium on the sale of the agricultural land argue that peasants will receive real money if they sell their land, but this requires a fair price for the land resources. According to valuation and annuity, Ukrainian lands are highly valued in the world. These are really the best lands. However, at present at an average price in the EU of about 10 thousand euros per hectare and above, up to 80 thousand euros in some regions of Europe, in Ukraine hectare of land is estimated ten times lower. The cost of the selling agricultural land in some European countries is shown in Figure 5[10].

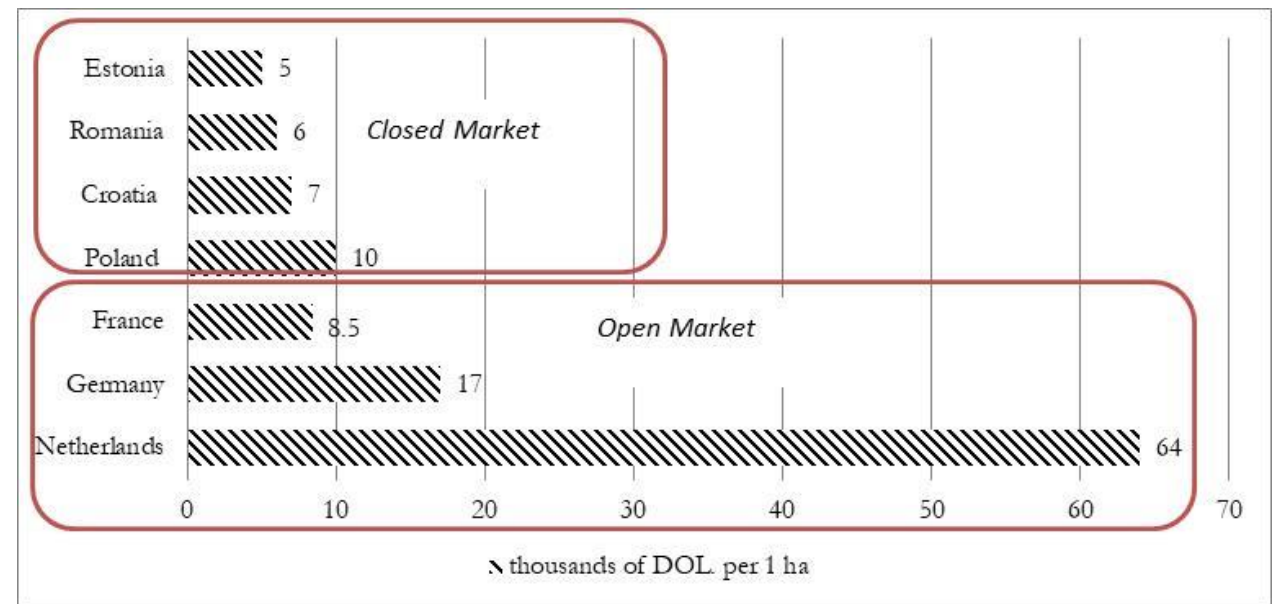

- The restrictions on access to the land market by EU Member States have been lifted since 1 May, 2016

Figure 5. Price for sale of the agricultural lands of individual countries, 2016 *

Source: developed by authors using data of Kyrylenko, I. (2017) [10].

In Ukraine after the property privatization ordinary Ukrainians and farmers have only land. Most of them will sell their holdings not because they have start-up capital for land work, but because they have no money.

The agrarian community has strong arguments for the excitement. For example, after the opening of the land market, its prices will be lower because of the significant excess of supply over demand. And this is already a great chance for the oligarchs to buy everything. Thus, they will turn into latifundists. Another problem is the uncertainty about the institution that will provide the long-term loans to farmers and other market participants at low credit rates. In order to give everyone an ability to buy land, it is necessary to have cheap credit resources of UAH 135 billion.

The farmers remind that we can not use the experience of the American market, which we are referred to as a standard because the land market was formed for centuries, but in Ukraine they want to do it during several months and years.

The uncontrolled land market which has developed in some Latin American countries where reforms have been carried out as carelessly as they are trying to do in Ukraine 
caused that the farmers became without lands. Indeed, more than $50 \%$ of Ukrainian citizens are afraid of the mass buying of Ukrainian lands by foreigners if the moratorium on the sale of Ukrainian lands will be abolished. To analyze this problem during the interrogation the list of potential threats was broken down into two groups: risks for the country and risks for the owners of the plots (Figure 6).

In addition, the respondents also noted the risks of the concentration of land in the property of a small number of people, the destruction of the Ukrainian village, the displacement of the small agricultural enterprises by agroholdings and the displacement of Ukrainian producers by foreign ones.

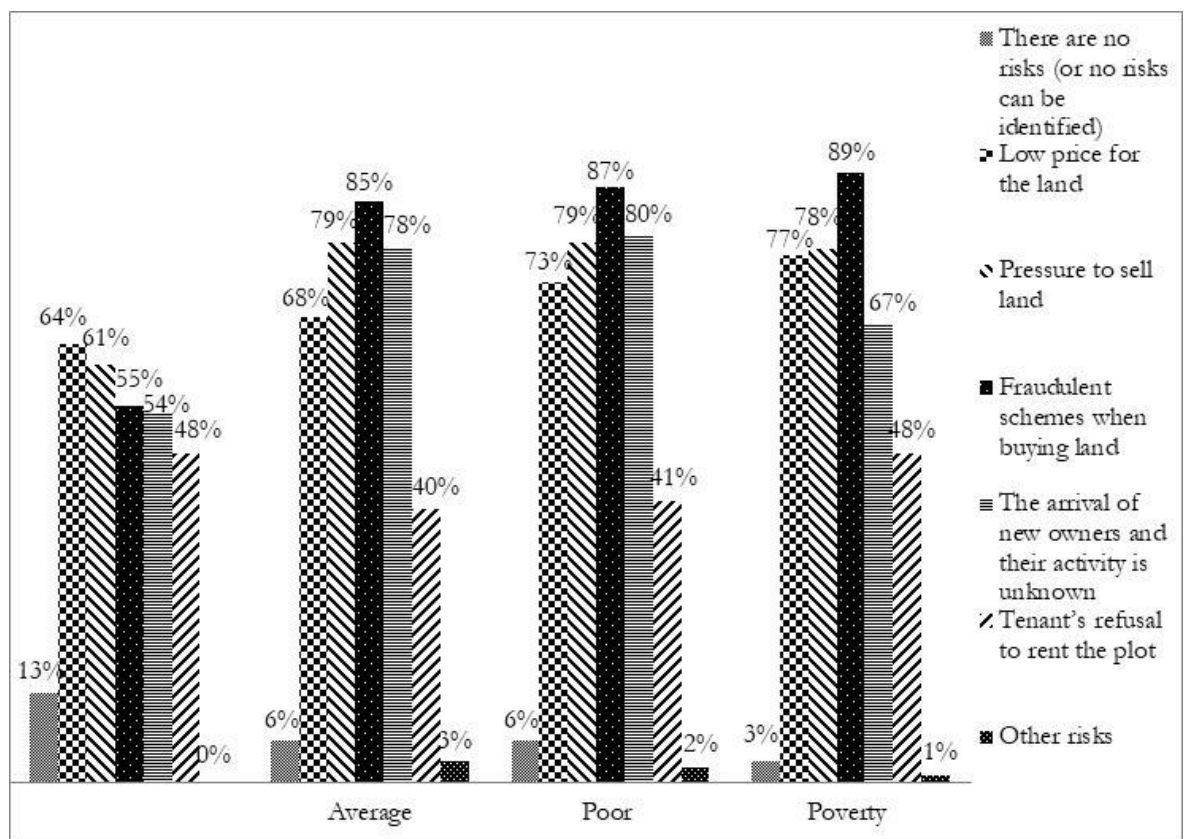

Figure 6. The dangers that unitholders and their families expect in case if the moratorium will be lifted (taking into account the household's financial situation)

Source: developed by authors using data of Agravery [11].

In general only $5 \%$ of the owners of the plots do not see any risk of lifting the moratorium for themselves and their families. Most of them are in high-income households (13\%) and the lowest among poor households (only 3\%). Most of the owners of the plots are afraid of low land prices, pressure to sell land and fraudulent schemes to buy land. The poorer families are the more serious they are at risk. For example, $55 \%$ of wealthy households consider likely the fraudulent schemes, compared to $89 \%$ of families that live in poverty.

By the way, it is the greatest risk for all owners of the plots, except wealthy. The significant proportion of the interviewed persons (in particular, $78 \%$ of the owners with middle-income and $80 \%$ of poor families) are worried about the possibility of the new owners whose activity will be unknown, - although it is obvious that they can manage both worse and better than previous ones. Such risks are not unreasonable, because 
when we analyze the statistics we can see the disproportion between the number of the land banks which is concentrated in the hands of the great latifundists and farmers.

About $89 \%$ of Ukrainian citizens indicate that the transmission of the information about the land plots in the electronic system typically involves certain errors, some of which are related to raiding. These types of errors are divided into technical and legal. In 2014 and 2 quarters of 2015 the errors were recorded in 124,577 plots (15\% of them in cities) with a total area of $462,711.8$ ha [6].

The privatization of more than $70 \%$ of the lands of the state property, mass registration of the private land plots, formation of the land lease market, launch of the digital State Land Cadastre in 2013 are the steps that were done in the land sector over the last 25 years. However, the lack of up-to-date and reliable data on the state of land resources and the land market is the main problem in the land reform. The cadastral system was not formed and maintained in Ukraine till nowadays. Not all lands were included into Land Cadastre $-30 \%$ remain outside. And the Register of property rights is not more than $14 \%$ of lands.

Also, there are no fuses to avoid the so-called "chess" when buying the land plots, because all plots are displayed in the coordinate system. Thus, if to acquire 140 hectares of land at an average share size of 4 hectares, which is 35 owners or $10 \%$ of the number of shareholders, it is simply unrealistic to ensure their effective use. In this case the instability and problems will arise for both buyers and those who currently rent this land. It will cause the reduction in agricultural output. It is possible to solve this problem by securing the land consolidation. So it is necessary to move away from the binding to the coordinate system, which is marked in the state act of the land property at present.

As a result, there are some problems, such as: determining the legal status and entering into the State Land Cadastre of the lands of collective property (unclaimed plots, field roads, forest strips and so on), plots of extinct heritage; opportunities to freely dispose of the private lands of the agricultural purpose and abolish the moratorium; attracting of the loans secured by the land plots and so on. They are not solved and the prospects for their legal settlement are not clear ate present.

Besides, the practice of applying existing legislation and regulations significantly differs between local authorities. The decentralization gives considerable opportunities for the use of the land resources, but it can increase corruption risks without transparency in the use of these resources.

The problems of the state land policy include the rapid development of the shadow land market because of the absence of the systematic restrictions on the land use; aggravation of the risk of investment in land because of the instability of the state land policy; the dispersion of agricultural land as a result of division into plots; growing of the parceling of farmland; cessation of the state financing of land protection measures; low efficiency of the land payment system; non-use of economic incentives and sanctions as economic levers of the land management; neglect of the state land turnover; politicization of the state management of land resources; neglect of the licensing activities; imperfection of the land legislation and so on.

Neither the state nor the farmers themselves are ready to open the agricultural land market at present. Therefore, the most important tools for opening the market should be the educational campaign on citizens' rights, the formation of the instruments for 
making unpopular political decisions, the development of the mortgage market and the introduction of temporary safeguards.

The analysis of the legislation of some developed countries shows that in each of them there are restrictions on the property of the agricultural land caused by the efforts to secure the protection of the agricultural land use, to stimulate the development of the agricultural structure, to prevent the inefficient parceling of the agricultural land. The effective land policy of the states concerning the agricultural lands is caused by the tasks of ensuring their own food security, formation of the dominant positions in the world food markets.

Europe and the world formed rules for land use and circulation or sale long time ago. The basic European standards that govern the land circulation and protection of the national interests should be included into our Law on the Land Market in Ukraine [12] which, in case of such fuses, could be at least 10 years ago [13].

The development of the scientifically based principles and of the use of land and the effective management of the land relations is the basis for the formation of an effective agrarian and social policy, which should be based on the implementation of the best norms concerning the functioning of the land market in the EU and the US (Table 2).

Table 2. Proposals for the regulation of the agricultural land market circulation in Ukraine and analysis of the world experience

\begin{tabular}{|c|c|}
\hline $\begin{array}{l}\text { Proposals of the Law on the Land Market } \\
\text { in Ukraine }\end{array}$ & $\begin{array}{l}\text { World norms (features) of the regulation of the market } \\
\text { circulation of agricultural lands in EU and US countries }\end{array}$ \\
\hline $\begin{array}{l}\text { At the first stage of the land market } \\
\text { introduction ( } 10 \text { years) an individual-citizen } \\
\text { of Ukraine who has lived in Ukraine for at } \\
\text { least } 5 \text { years can be the buyer of the land. } \\
\text { In future the legal entities registered under } \\
\text { the current legislation of Ukraine, as well as } \\
\text { foreign individuals and legal entities may be } \\
\text { the buyers of land. After the acquisition of } \\
\text { the land into the property the owner } \\
\text { should reside territorially at the place of his } \\
\text { property. }\end{array}$ & $\begin{array}{l}\text { France - citizens and their associations, municipalities and } \\
\text { state may be buyers of agricultural land. } \\
\text { Germany - individuals and legal entities, territorial } \\
\text { communities, federal states and state may be buyers of } \\
\text { agricultural land. } \\
\text { Poland - the buyer of the land must confirm his intention to } \\
\text { cultivate the land independently and reside in a commune } \\
\text { where the land or neighboring commune is located for at least } \\
5 \text { years. } \\
\text { Denmark - a Danish farmer is obliged to reside at the place } \\
\text { of their territorial location after the acquisition of agricultural } \\
\text { land. }\end{array}$ \\
\hline $\begin{array}{l}\text { The buyer of the Ukrainian land has a } \\
\text { Ukrainian agricultural education, has at } \\
\text { least } 3 \text { years of experience in the } \\
\text { agriculture of Ukraine and be personally } \\
\text { involved in agricultural production. }\end{array}$ & $\begin{array}{l}\text { Denmark - before concluding the sale and purchase of the } \\
\text { land the potential buyer should confirm the existence of the } \\
\text { appropriate agricultural education and give a written } \\
\text { undertaking that he or she will be managing the land for at } \\
\text { least } 8 \text { years. } \\
\text { France - the Society for Land Management and Rural } \\
\text { Development (SAFER) envisages that the land can be bought } \\
\text { not by the person which has money, but has relevant } \\
\text { agricultural experience and intends to work on French land. } \\
\text { Germany - the preference is given to young farmers under } \\
\text { the age of } 40 \text { and farmers who intend to engage in organic } \\
\text { farming. In case of intention to purchase the land by a person } \\
\text { who is not a farmer the territorial community can buy it. } \\
\text { Poland - the preferential land purchase rights are given to the } \\
\text { farmers which have secondary or higher education and } \\
\text { agricultural experience at least } 5 \text { years. }\end{array}$ \\
\hline
\end{tabular}




\begin{tabular}{|l|l|}
\hline $\begin{array}{l}\text { Proposals of the Law on the Land Market } \\
\text { in Ukraine }\end{array}$ & $\begin{array}{l}\text { World norms (features) of the regulation of the market } \\
\text { circulation of agricultural lands in EU and US countries }\end{array}$ \\
\hline $\begin{array}{l}\text { Not more than 500 hectares per citizen } \\
\text { (into one hand). }\end{array}$ & $\begin{array}{l}\text { Limiting land sizes: } \\
\text { USA - 800 hectares; } \\
\text { Spain - 250 hectares; } \\
\text { France - 150 hectares; } \\
\text { Poland - 500 hectares; } \\
\text { Romania - 100 hectares; } \\
\text { Hungary - 300 hectares; } \\
\text { Denmark - 150 hectares. }\end{array}$ \\
\hline $\begin{array}{l}\text { Preferential loans in UAH } \\
2-3 \% \text { per annum. }\end{array}$ & $\begin{array}{l}\text { Poland - for 15 years at 2\% per annum; } \\
\text { Latvia - for 20 years at 3.3\% per annum (the maximum } \\
\text { loan amount is EUR } 140 \text { thousand). }\end{array}$ \\
\hline
\end{tabular}

Source: developed by authors using data from [12], [13]

\section{Conclusions}

The land reform and land relations built on it can provide the desired effect in case of the political and organizational support of the state, financial, tax, material and technical orientation on the implementation of the village model of the development of domestic agriculture and its stable growth; social justice; peasants' confidence in the stability of the agricultural policy of the state, and the stability of the legislative base.

Having analyzed the current state of affairs in Ukraine we can argued that it is not possible to open the land market because the corruption is not restored and the confidence in the judicial branch is not renewed.

The US and Europe are in no hurry to sell the state lands. The percentage of the private land is only $40 \%$. The fact remains. It is not already tens, but hundreds of years the countries which we take an example do not change the rules for the circulation of the agricultural land.

\section{References}

Kaletnik, G., Shubravska, O., Ibatullin, M., Krysanov, D., Starychenko, Y., Tkachenko, K., Varchenko, O. (2019). Features of Food Security of the Country in Conditions of Economic Instability. Int. J. Manag. Bus. Res, 9 (4): 176-186.

Popek, S., Sikora, T. (2005). Food and Agricultural Industry in Poland after European Union Accession. The food industry in Europe, 5: 75-84. Available at: http://www.ip.aua.gr/studies.asp.

Butnaru, S.E. (2015). The Effects of Liberalization on the Romanian Land Market Sales. Some Current Issues in Economics. - Komárno: International Research Institute sro., 209-217.

Lupenko, Y., Khodakivska, O. (2016). Scientific principles of introduction of market circulation of agricultural lands. Economy APK, 12: 5-15. Available at: http: //nbuv.gov.ua/UJRN/E_apk_2016_12_3.

Official site of the State Statistics Service of Ukraine. Available at: http://www.ukrstat.gov.ua/.

Official site of the State Geocadastre. Yearbook «Monitoring of Land Relations in Ukraine. 2014-2015». Available at: http://land.gov.ua/wp-content/uploads/2016/03/.

Khodakivska, O. (2015). Land relations in agriculture: state, problems, prospects of development. Land management newsletter, 7: 18-22.

The average size of the land share (share) by region. Available at: https://docs.dtkt.ua/download/pdf/1221.616.1.

Official site of the State Geocadastre. Yearbook «Monitoring of Land Relations in Ukraine. 2016-2017. Available at: http://land.gov.ua/wp-content/uploads/2018/10/monitoring.pdf. 
Kyrylenko, I. (2017). Capitalization of land resources in the conditions of development and transformation of land relations in Ukraine. Economy. Finances. Management: topical issues of science and practice, 12 (28): 7-20.

Yaremko, V., Niev'evskiy, O., Zarytska, M. (2017). Why are Ukrainians afraid of the agricultural land market and are these concerns justified? Agravery. Available at: http://agravery.com/uk/posts/show/comuukrainci-boatsa-rinku-silgospzemel-ta-ci-vipravdani-ci-pobouvanna.

Draft Law on Amendments to Certain Legislative Acts of Ukraine on the Circulation of Agricultural Lands. Available at: http://w1.c1.rada.gov.ua/pls/zweb2/webproc4_1?pf3511=66948

Zalutsky, I. (2017). Unblocking the moratorium on the circulation of agricultural land in the context of the priority of their protection. Regional Economy, 2(84): 105-115.

On measures to implement the Presidential Decree of November 10, 1994 N 666/94 «On urgent measures to accelerate land reforms in the field of agricultural production». Available at: https://zakon.rada.gov.ua/laws/show/793-94-\%D0\%BF.

Law of Ukraine «About land lease». Available at: https://zakon.rada.gov.ua/laws/show/161-14.

Zhaohui Hong, Yi Sun (2020). Power, capital, and the poverty of farmers' land rights in China. Land Use Policy, 92. https://doi.org/10.1016/j.landusepol.2020.104471.

Berta, F., North, M., Rovere, S., Tatara, E., Macal, C., Podestá, G. (2015). Simulating agricultural land rental markets by combining agent-based models with traditional economics concepts: The case of the Argentine Pampas. Environmental Modelling \& Software, 71: 97-110. https://doi.org/10.1016/j.envsoft.2015.05.005.

Gladiy, M. (2020). Land reform: current problems and solutions. Economy APK, 2: 6. https://doi.org/10.32317/2221-1055.202002006.

Varchenko, O.M., Krysanov, D.F., Shubravska, O.V., Khakhula, L.P., Gavryk, O.Y., Byba, V.A., Honcharuk, I.V. (2020). Supply Chain Strategy in Modernization of State Support Instruments for Small Farms in Ukraine. International Journal of Supply Chain Management, 9 (1): 536-543.

Palamarchuk, V., Honcharuk, I., Honcharuk, T., Telekalo, N. (2018). Effect of the elements of corn cultivation technology on bioethanol production under conditions of the right-bank forest-steppe of Ukraine. Ukrainian Journal of Ecology, 8, 3: 42-50. Available at: https://www.ujecology.com/articles/effect-of-the-elements-of-corn-cultivation-technology-onbioethanol-production-under-conditions-of-the-rightbank-forests.pdf. 